\title{
Molecular Characterization of a Begomovirus and Betasatellite Causing Yellow Vein Net Disease of Ageratum houstonianum
}

\author{
Ashish Srivastava, Susheel Kumar, and Shri Krishna Raj, Plant Molecular Virology Laboratory, CSIR-National Botanical Research
} Institute (NBRI), Rana Pratap Marg, Lucknow 226001, India

\begin{abstract}
Srivastava, A., Kumar, S., Raj, and S. K. 2015. Molecular characterization of a begomovirus and betasatellite causing yellow vein net disease of Ageratum houstonianum. Plant Dis. 99:627-631.

Ageratum houstonianum was introduced in India as an annual ornamental plant and is grown in beds for blue head flowers. Yellow vein net disease was observed on A. houstonianum plants with about $9.0 \%$ disease incidence during a survey in February 2012 at gardens of NBRI, Lucknow, India. Association of a begomovirus and betasatellite with the disease was characterized based on sequence analyses of their cloned full length genome isolated from diseased A. houstonianum. Sequence analysis of the begomovirus showed presence of the six open reading frames in its genome, similar to the arrangement of Old World begomoviruses. The begomoviral genome shared 95 to $97 \%$ sequence identities with various strains of Ageratum enation virus (AEV); however, it showed

distinct phylogenetic relationships with them, and hence was identified as a variant of AEV based on more than $94 \%$ sequence homology, the criteria defined by ICTV. The sequence analysis of associated betasatellite revealed highest $93 \%$ sequence identity and close phylogenetic relationships with Ageratum leaf curl betasatellite (ALCB) molecules; therefore, it was identified as an isolate of ALCB (based on 93\% sequence homology). Agroinfiltration of partial dimers of the AEV variant and ALCB induced similar systemic yellow vein net and leaf curl symptoms on $A$. houstonianum when infiltrated in combination, fulfilling Koch's postulates. Characterization of AEV and ALCB causing yellow vein net disease of $A$. houstonianum is being reported for the first time.
\end{abstract}

Ageratum houstonianum (syn. Ageratum mexicanum Hort.), of family Asteraceae, is a cool-season annual plant often grown as bedding plant in gardens, and is native to South and Central America (11). It has been introduced in India as an annual ornamental plant and is grown in beds for blue head flowers. A. houstonianum has been reported as the natural host of Ageratum latent virus (ALV), an Ilarvirus $(12,25)$ and Ageratum houstonianum potyvirus (unpublished data, GenBank Accession No. AJ867580). Three characterized begomoviruses, Ageratum yellow vein virus (AYVV) $(33,34)$ from Singapore, Ageratum yellow vein China virus (AYVCV) (35), and Ageratum leaf curl virus (ALCV) (9) from China have been reported on Ageratum conyzoides.

Begomovirus is the largest genus of family Geminiviridae and reported to transmitted by whiteflies (5). Old World begomovirus are generally monopartite and contain six open reading frames (ORFs): V2 and V1 in virion sense strand, and C3, C2, C1, and C4 in complementary sense strand which are required for replication, encapsidation, and systemic movement of the virus within host plant. A novel component referred to as betasatellite has been found to be associated with most of the monopartite begomoviruses, which is approximately $1.3 \mathrm{~kb}$ in size and it depends entirely upon the helper virus for its replication, encapsidation, and cell-to-cell movement $(3,22)$. In Old World, most begomoviruses have monopartite genomes and the majority of them are associated with the symptom modulating ssDNA satellites as betasatellite (24). Some nanoviruslike DNA components, known as alphasatellites, have also been reported with many begomovirus disease complexes (4).

Ageratum enation virus (AEV), a begomovirus, was first isolated from a weed in 2005 (A. conyzoides: Nepal, Accession No. NC_003434). AEV has a very large host range including weeds and economical important plants. AEV is reported to infect Zinnia elegans and A. conyzoides from Palampur (14,15), Amaranthus

Corresponding author: Shri Krishna Raj, E-mail: skraj2@rediffmail.com

Accepted for publication 13 October 2014.

http://dx.doi.org/10.1094/PDIS-03-14-0333-RE

(C) 2015 The American Phytopathological Society cruentus (29), Tagetes patula (16), Solanum lycopersicum (31), and Carica papaya (27). Ageratum leaf curl betasatellite (ALCB) was isolated from A. conyzoides (AM698010) and Brassica rapa (AM701771) in Pakistan. ALCB has also been reported in India from T. patula (16), A. cruentus, and A. hypochondriacus $(28,29)$. However, AEV and ALCB molecules causing yellow vein net disease of $A$. houstonianum have not been investigated hitherto. In this communication, we report the characterization of AEV and ALCB causing yellow vein net disease of $A$. houstonianum.

\section{Materials and Methods}

Sample collection and whitefly transmission. Nine leaf samples from naturally infected $A$. houstonianum plants showing yellow vein net accompanied with leaf curl symptoms were collected from gardens of National Botanical Research Institute, Lucknow, India, during a survey in February 2012, to observe virus disease like symptoms on annual ornamentals. Based on typical yellow vein net symptoms and population of whiteflies in the vicinity, the begomovirus infection was suspected; therefore, a whitefly transmission test was attempted. For transmission of the infecting virus, whitefly transmission test was conducted as described earlier (26) using 10 whiteflies (Bemisia tabaci) per plant. Briefly, the adult whiteflies were collected from healthy cotton plants and starved for $2 \mathrm{~h}$, then allowed to feed on infected A. houstonianum plant showing yellow vein mosaic symptoms for an acquisition access period (AAP) of $24 \mathrm{~h}$. These viruliferous whiteflies were transferred onto five healthy seedlings of $A$. houstonianum and allowed a $24 \mathrm{~h}$ inoculation access period (IAP). Ten nonviruliferous whiteflies were also allowed to feed on a set of five plants taken as control. Then, whiteflies were killed by spraying Dimecron $0.1 \%(\mathrm{v} / \mathrm{v})$ and the test plants were monitored for symptoms for 60 days postinoculation (dpi).

Detection of begomovirus and betasatellite by PCR. For molecular detection of the infecting begomovirus, total genomic DNA was isolated from $100 \mathrm{mg}$ leaf tissue of nine samples (SKR1 to SKR9) of symptomatic A. houstonianum plants using DNeasy Plant Mini Kit (QIAGEN GmbH, Hilden, Germany) and PCR was performed with begomovirus DNA-A specific primers (PAL1v1978/ PAR1c496) (20). PCR was carried out in a thermal cycler (Super cycler 8800 , Agilent Technology, Petaling Jaya, Selangor, Malaysia) with the conditions: initial denaturation at $94^{\circ} \mathrm{C}$ for $5 \mathrm{~min}$, followed by 30 
cycles of denaturation at $94^{\circ} \mathrm{C}$ for $1 \mathrm{~min}$; annealing for $1 \mathrm{~min}$ at $52^{\circ} \mathrm{C}$, extension at $72^{\circ} \mathrm{C}$ for $1.5 \mathrm{~min}$, and final extension step was $5 \mathrm{~min}$ at $72^{\circ} \mathrm{C}$.

To detect the association of DNA-B genome with begomovirus, PCR was performed with DNA-B genome specific primers (BC1F and BC1R) (17). The PCR were conducted at $94^{\circ} \mathrm{C}$ for $5 \mathrm{~min}$ for denaturation, followed by 30 cycles of $94^{\circ} \mathrm{C}$ for $1 \mathrm{~min}, 52^{\circ} \mathrm{C}$ for $1 \mathrm{~min}$, $72^{\circ} \mathrm{C}$ for $1 \mathrm{~min}$, and final extension at $72^{\circ} \mathrm{C}$ for $5 \mathrm{~min}$.

PCR was also performed to amplify the betasatellite molecule using beta 01 and beta 02 primers (3). PCR was conducted at $94^{\circ} \mathrm{C}$ for $5 \mathrm{~min}$ for denaturation, followed by 30 cycles of $94^{\circ} \mathrm{C}$ for $1 \mathrm{~min}$, $50^{\circ} \mathrm{C}$ for $1 \mathrm{~min}, 72^{\circ} \mathrm{C}$ for $1.5 \mathrm{~min}$, and final extension at $72^{\circ} \mathrm{C}$ for 5 min. PCR was also performed using alphasatellite (6) specific primers and genomic DNA of same samples. The PCR conditions for were: $94^{\circ} \mathrm{C}$ for $5 \mathrm{~min}$ for denaturation, followed by 30 cycles of $94^{\circ} \mathrm{C}$ for $1 \mathrm{~min}$ for denaturation, $50^{\circ} \mathrm{C}$ for $1 \mathrm{~min}$ for annealing, $72^{\circ} \mathrm{C}$ for $1 \mathrm{~min}$ for extension, and final extension at $72^{\circ} \mathrm{C}$ for $5 \mathrm{~min}$.

All the PCR products were resolved in $1.0 \%$ agarose gel by electrophoresis in $1 \times$ TAE buffer along with $1 \mathrm{~kb}$ DNA ladder (Thermo Fisher Scientific Inc., Pittsburgh, PA).

Full length genome amplification by rolling circle amplification. For molecular identification of the begomovirus isolate, total DNA was isolated from $100 \mathrm{mg}$ of each of three symptomatic leave samples (SKR1, SKR2, and SKR3) of A. houstonianum using a DNeasy Plant Mini Kit and full-length viral genome was amplified using rolling circle amplification (RCA) method (8) based TempliPhi DNA amplification kit (GE Healthcare, Buckinghamshire, UK). RCA reaction was performed using $\varnothing-29$ DNA polymerase as per manufacturer's instructions. The RCA product was monomerized by digestion with $\mathrm{XbaI}, \mathrm{XhoI}$, and BamHI restriction enzymes (New England BioLabs Ltd., Knowl Piece, Hitchin, UK) as described earlier (29) and analyzed on $1.0 \%$ agarose gel. Three RCA products obtained by digestion by BamHI were cloned into pCAMBIA1300 vector and sequenced by primer walking (GeNei Pvt. Ltd., Bangalore, India).

Sequence analyses of begomovirus and betasatellite molecules. The sequence data of the begomovirus and betasatellite molecules was initially analyzed by BLASTn (1) for sequence identities. For the identification of functional ORF, the ExPASy translation tool (http://www. expasy.org/tools/dna.html) was used. The sequences of begomovirus (under study) were also aligned with respective sequences of selected AEV strains and other begomoviruses (selected on the basis of BLASTn) by ClustalW method using Genomatix DiAlign program (http://www.genome.jp/tools/clustalw/). The phylogenetic relationships of the begomovirus and betasatellite molecules under study were obtained by the phylogenetic tree generated by Molecular Evolutionary Genetics Analysis (MEGA v5.1) tool, using neighbor-joining method with 1,000 replicates bootstrapping values (32).

Agroinfectious clones and infectivity tests. To determine the infectivity of begomovirus and betasatellite molecules, their infectious clones were generated into pCAMBIA1300 vector backbone. For infectious clones of the begomovirus, the genome was digested with EcoRI and BamHI enzyme and ligated in pCAMBIA1300 vector at EcoRI/BamHI site, and then a full length BamHI digested begomovirus genome was religated. For infectious clones of the betasatellite, the betasatellite DNA was digested with $K p n I$ and HindIII and ligated in pCAMBIA1300 vector and then a full length $K p n I$ digested betasatellite DNA molecule was religated in same construct. The method described earlier (29) was used for generating the agroinfectious clones.

The orientations of both the infectious clones were determined by their sequencing and analysis of their sequence data. The checked clones were mobilized into Agrobacterium tumefaciens strain GV3101 and were designated as pCAM-AEV-As (for begomovirus clone) and pCAM-ALCB-As (for betasatellite clone). Both the clones were suspended in MES buffer to 1.0 OD and infiltrated into lower surface of leaves of A. houstonianum, A. conyzoides, Nicotiana glutinosa, and $N$. benthamiana seedlings (five seedlings for each) in combination and/or alone and with a negative control (pCAMBIA1300 vector) using $2 \mathrm{ml}$ syringe by pressure infiltration method (10). Five plants were mock inoculated using MES buffer as control. Agroinfiltrated plants were maintained in insect proof glasshouse and monitored for 2 months for symptom development.

\section{Results}

Symptomatology, disease incidence, and whitefly transmission. During the survey in February 2012, yellow vein net disease was observed on 88 out of 944 A. houstonianum plants (with about $9.0 \%$ disease incidence) growing in beds at gardens of NBRI, Lucknow. The diseased plants showed mild to severe yellow vein net accompanied with leaf curl symptoms (Fig. 1a and b). Based on typical yellow vein net symptoms and population of whiteflies in the vicinity, the begomovirus infection was suspected. Whitefly transmission resulted in successful transmission of the pathogen from naturally infected $A$. houstonianum to healthy $A$. houstonianum seedlings (5/5) at 40 to $45 \mathrm{dpi}$ as compared with the control plants (nonviruliferous whitefly inoculated plants), indicating the association of begomovirus with the disease.

Detection of begomovirus and associated satellite molecules. During PCR using total genomic DNA isolated from leaf samples of A. houstonianum plants and begomovirus DNA-A specific primers (20), an expected size amplicon of approximately $1.1 \mathrm{~kb}$ was successfully amplified from all (9/9) samples (SKR1 to SKR9) of symptomatic $A$. houstonianum plants. The whitefly inoculated $A$. houstonianum plants, when tested by PCR, also showed approximately $1.1 \mathrm{~kb}$ amplification (5/5 plants), indicating the presence of begomovirus. However, our several attempts failed to amplify the DNA-B component from these symptomatic plant samples using DNA-B specific primers (17) during PCR which indicated absence of DNA-B genome, suggesting the begomovirus isolate under study as a monopartite begomovirus.

The agarose gel electrophoresis of PCR products using betasatellite specific primers (3) resulted in amplification of approximately $1.3 \mathrm{~kb}$ amplicon in all the nine A. houstonianum samples (SKR1 to SKR9), indicating presence of betasatellite molecule associated with the begomovirus disease. However, no such amplicon could be obtained from any of $A$. houstonianum samples using alphasatellite specific primes (6), suggesting absence of alphasatellite molecule.

Full length begomoviral genome amplification by RCA and its sequence analysis. For molecular characterization of the begomovirus, full-length viral genome was amplified using DNA isolated from three infected A. houstonianum (SKR1, SKR2, and SKR3) and Ø29 DNA polymerase by RCA followed by separate digestion with BamHI, XbaI, and XhoI restriction enzymes. The analysis of RCA digested products on $1.0 \%$ agarose gel revealed in a band corresponding to approximately $2.7 \mathrm{~kb}$ by $B a m \mathrm{HI}$ in all three samples but not by $X b a \mathrm{I}$ and $X h o \mathrm{I}$ enzymes (data not shown). The approximately $2.7 \mathrm{~kb}$ bands obtained from all three samples were cloned and sequenced by primer walking. The full length sequences obtained from three samples were $100 \%$ similar; therefore, one representative sequence of the complete genome of 2,753 nucleotides was submitted in GenBank under accession number JQ911767.

The sequence analysis of begomovirus under study (JQ911767) showed six potential ORFs: V2 (precoat protein) and V1 (coat protein) in virion sense strand, while $\mathrm{C} 3$ (replication enhancer protein), $\mathrm{C} 2$ (transcription activator protein), $\mathrm{C} 1$ (replicase protein), and $\mathrm{C} 4$ (C4 protein) in complementary sense strand, which were arranged similar to those of the typical Old World begomoviruses. BLASTn analysis of the sequence data revealed highest $98 \%$ sequence identity with Ageratum enation virus (AEV) isolated from Solanum lycopersicum (JX436472) and Trigonella foenum-graecum (JX436473), and 93 to $97 \%$ with other strains of AEV reported worldwide. During the Genomatix Dialign analysis, the begomovirus under study (JQ911767) shared highest 97\% identity with four AEV: S. lycopersicum (JX436472), A. conyzoides (FN794198, FN794201), and Zinnia elegans (FN543099), and 95 to $96 \%$ identities with the other AEV strains taken for the study (Table 1). The amino acid sequences of the virus isolate showed highest $100 \%$ sequence identity at precoat protein (V2) level and the lowest $89 \%$ at replication enhancer protein (C3) level with AEV of $S$. lycopersicum isolate (Table 1). The 
identities of the ORFs of begomovirus under study at amino acids were: 96 to 98,99 to 100,88 to 90,88 to 91,96 to 97 , and 96 to $100 \%$ at V2, V1, C3, C2, C1, and C4 levels, respectively.

During phylogenetic analysis of the begomovirus along with the begomovirus isolates taken for study, clustered into four groups: AEV, Radish leaf curl virus (RaLCV), Tobacco curly shoot virus (TobCSV), and Tomato leaf curl Karnataka virus (ToLCKV), and begomovirus isolate under study fell in a clade with other AEV isolates. Although the isolate under study grouped together with AEV isolates, it showed a distinct relationship with them (Fig. 2). Based on the highest nucleotide sequence identities (95 to 97\%) of the complete genome, distinct phylogenetic relationships with various AEV isolates and as per begomovirus nomenclature criteria defined by ICTV (7), the begomovirus under study has been identified as a variant of AEV.
Sequence analysis of betasatellite molecule. The betasatellite amplicon of approximately $1.3 \mathrm{~kb}$ was obtained, cloned, and sequenced (JQ408218) from the SKR1 sample as the AEV clone. The BLASTn analysis of betasatellite molecule showed highest 93\% sequence identity with Ageratum leaf curl betasatellite (ALCB) isolated from A. hypochondriacus (JQ408218). During phylogenetic analysis, the betasatellite under study clustered with three ALCB isolates and showed close relationship with them (Fig. 3). Based on the high $93 \%$ sequence identity and a close phylogenetic relationship, the betasatellite under study was identified as ALCB.

Agroinfectivity of begomovirus and betasatellite molecules. Agroinfiltration of pCAM-AEV-As and pCAM-ALCB-As were done in combination and alone on A. houstonianum, A. conyzoides, $N$. glutinosa, and $N$. benthamiana plants. Infiltration of infectious clones in combination (of pCAM-AEV-As and pCAM-ALCB-As)
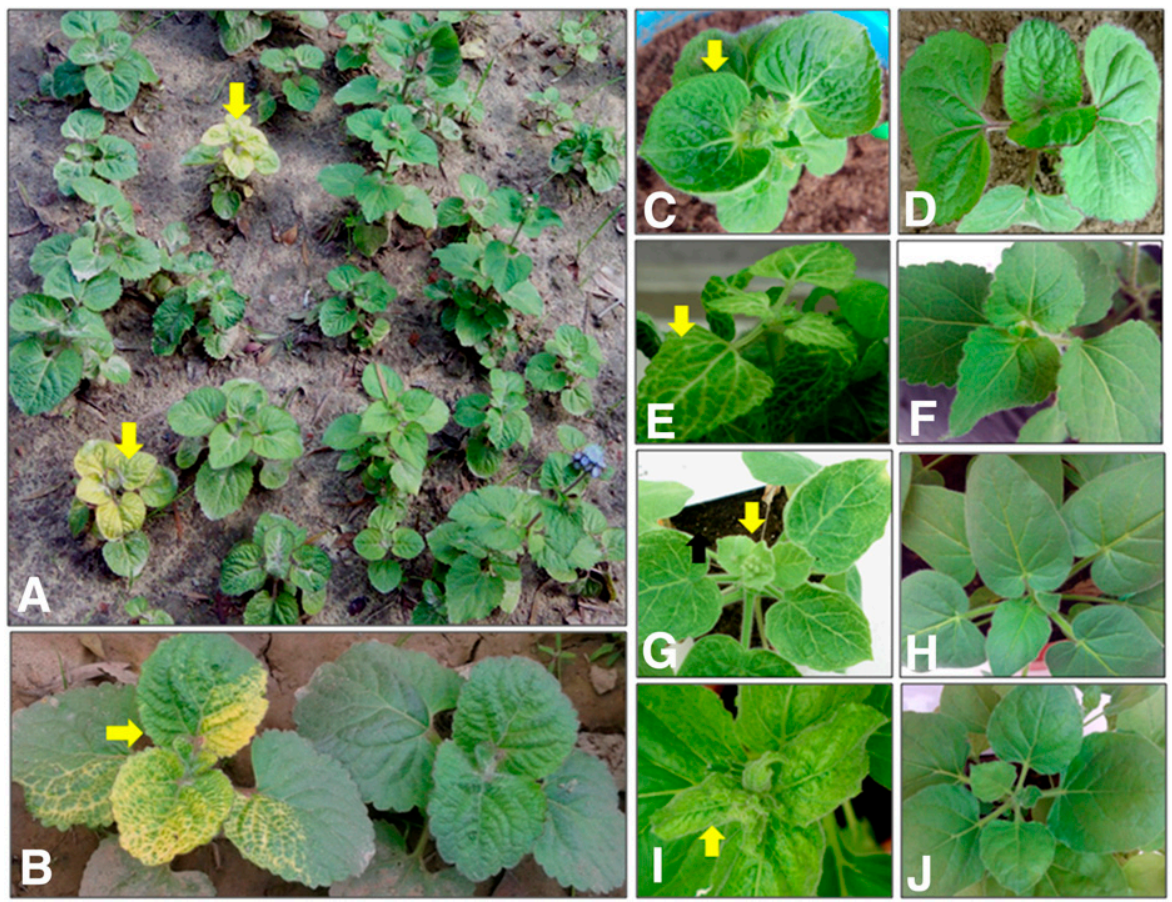

Fig. 1. Naturally infected Ageratum houstonianum showing yellow vein net and leaf curl symptoms in field (A) and yellow vein net diseased and healthy plants for comparison in a closed view (B). Agroinfiltrated plants with pCAM-AEV-As and PCAM-ALCB-As clones (in combination) showing mild yellow vein net and leaf curl symptoms on A. houstonianum (C), A. conyzoides (E), Nicotiana glutinosa (G), and N. benthamiana (I) at 35 to 40 days post inoculation as compared with the respective control plants (D, F, H and J). The symptoms on leaves of infected plants have been indicated by yellow arrows.

Table 1. Sequence identities of Ageratum enation virus strain of Ageratum houstonianum (JQ911767) with AEV strains and other selected begomovirus genomes at nucleotide (nt) and their ORFs at amino acid (aa) levels obtained by Genomatix DiAlign analysis

\begin{tabular}{|c|c|c|c|c|c|c|c|c|c|c|}
\hline \multirow[b]{2}{*}{ Accessions } & \multirow[b]{2}{*}{ Virus $^{\mathbf{a}}$} & \multirow[b]{2}{*}{ Host } & \multirow[b]{2}{*}{ Location in India } & \multicolumn{7}{|c|}{ Percent $(\%)$ identities at the level of } \\
\hline & & & & DNA genome (nt) & V2 (aa) & V1 (aa) & $\mathrm{C3}$ (aa) & C2 (aa) & C1 (aa) & C4 (aa) \\
\hline JX436472 & AEV & Solanum lycopersicum & Karnataka & 97 & 98 & 100 & 89 & 91 & 96 & 100 \\
\hline FN794198 & $\mathrm{AEV}$ & Ageratum sp. & Palampur & 97 & 96 & 100 & 90 & 91 & 97 & 100 \\
\hline FN794201 & AEV & Ageratum conyzoides & Palampur & 97 & 97 & 100 & 90 & 91 & 96 & 98 \\
\hline FN543099 & $\mathrm{AEV}$ & Zinnia sp. & Palampur & 97 & 97 & 100 & 90 & 91 & 96 & 100 \\
\hline JX436473 & $\mathrm{AEV}$ & Trigonella foenum-graecum & Karnataka & 96 & 97 & 99 & 88 & 91 & 96 & 98 \\
\hline JF682242 & AEV & Amaranthus hypochondriacus & Lucknow & 96 & 97 & 99 & 88 & 91 & 96 & 96 \\
\hline JF728864 & AEV & A. conyzoides & Mohali & 96 & 98 & 100 & 88 & 88 & 96 & 98 \\
\hline JF728866 & $\mathrm{AEV}$ & A. conyzoides & Mohali & 95 & 98 & 100 & 88 & 88 & 97 & 98 \\
\hline JX457342 & TobCSV & S. lycopersicum & Karnataka & 85 & 96 & 99 & 92 & 88 & 81 & 52 \\
\hline EF175733 & RaLCV & Raphanus sativus & Varansi & 85 & 94 & 99 & 90 & 91 & 85 & 69 \\
\hline EU194914 & RaLCV & Nicotiana tabacum & Samastipur & 84 & 96 & 98 & 91 & 91 & 86 & 75 \\
\hline JX467693 & TobCSV & S. lycopersicum & Karnataka & 84 & 96 & 99 & 91 & 88 & 81 & 52 \\
\hline HM803118 & ToLCKV & S. lycopersicum & New Delhi & 79 & 95 & 97 & 88 & 84 & 80 & 51 \\
\hline HM851186 & ToLCKV & S. lycopersicum & New Delhi & 78 & 94 & 97 & 88 & 84 & 80 & 51 \\
\hline
\end{tabular}

a AEV = Ageratum enation virus, RaLCV = Radish leaf curl virus, TobCSV = Tobacco curly shoot virus, ToLCKV = Tomato leaf curl Karnataka virus. 
induced yellow vein net and leaf curl symptoms on A. houstonianum (Fig. 1c) at 35 to $40 \mathrm{dpi}$, which were similar to those of naturally infected A. houstonianum, fulfilling Koch's postulates. The yellow vein net and leaf curl symptoms were obtained on A. conyzoides (Fig. 1e), N. glutinosa (Fig. 1g), and N. benthamiana (Fig. 1i). The mild yellow vein net and leaf curl symptoms were also induced on these plants when agroinfiltrated by pCAM-AEV-As alone, while no such symptoms could be obtained either on plants infiltrated with pCAM-ALCB-As alone or using MES buffer (mock inoculated plants taken as control) (Fig. 1d, f, h, and j).
All the inoculated plants were checked for replication of AEV genome and betasatellite by PCR using begomovirus (20) and betasatellite (3) specific primers and DNA isolated from the upper leaves of inoculated plants. The PCR showed positive amplicons of expected size in all plants inoculated with pCAM-AEV-As and pCAM-ALCB-As in combination, and pCAM-AEV-As alone by begomovirus specific primers. Betasatellite specific primers also resulted in positive amplification in the plants inoculated with combination of both, but not in plants inoculated either by pCAM-AEVAs or pCAM-ALCB-As alone. These results suggested that AEV

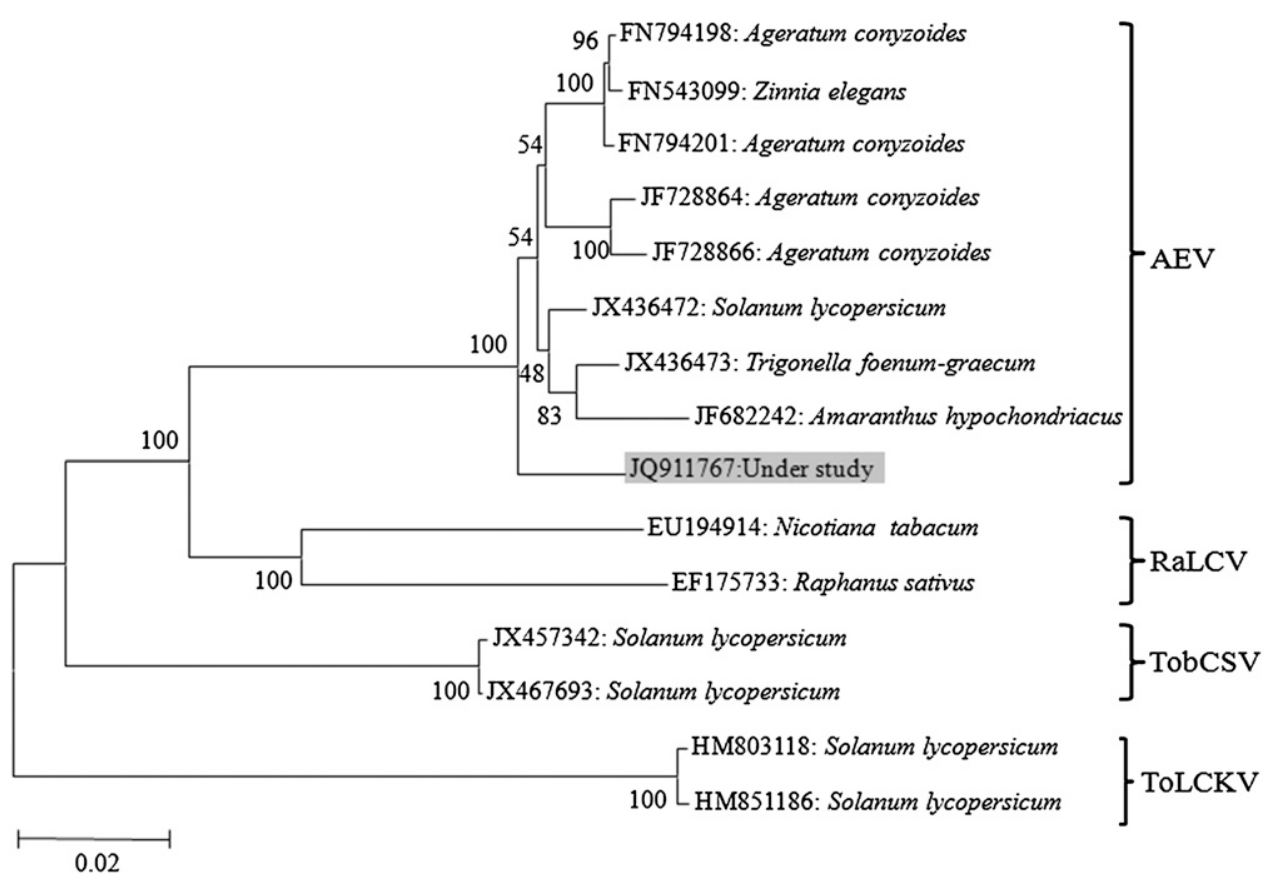

Fig. 2. Phylogenetic relationships of begomovirus under study (JX436472) of Ageratum houstonianum with respective sequence data of selected begomoviruses reported worldwide. Phylogenetic analysis was performed by MEGA v. 5.1 with 1,000 replicates bootstrapping and the dendrogram was generated with NJ-method and viewed by NJ plot program. Abbreviations used for this study: AEV = Ageratum enation virus, RaLCV $=$ Radish leaf curl virus, TobCSV $=$ Tobacco curly shoot virus, and ToLCKV $=$ Tomato leaf curl Karnataka virus.

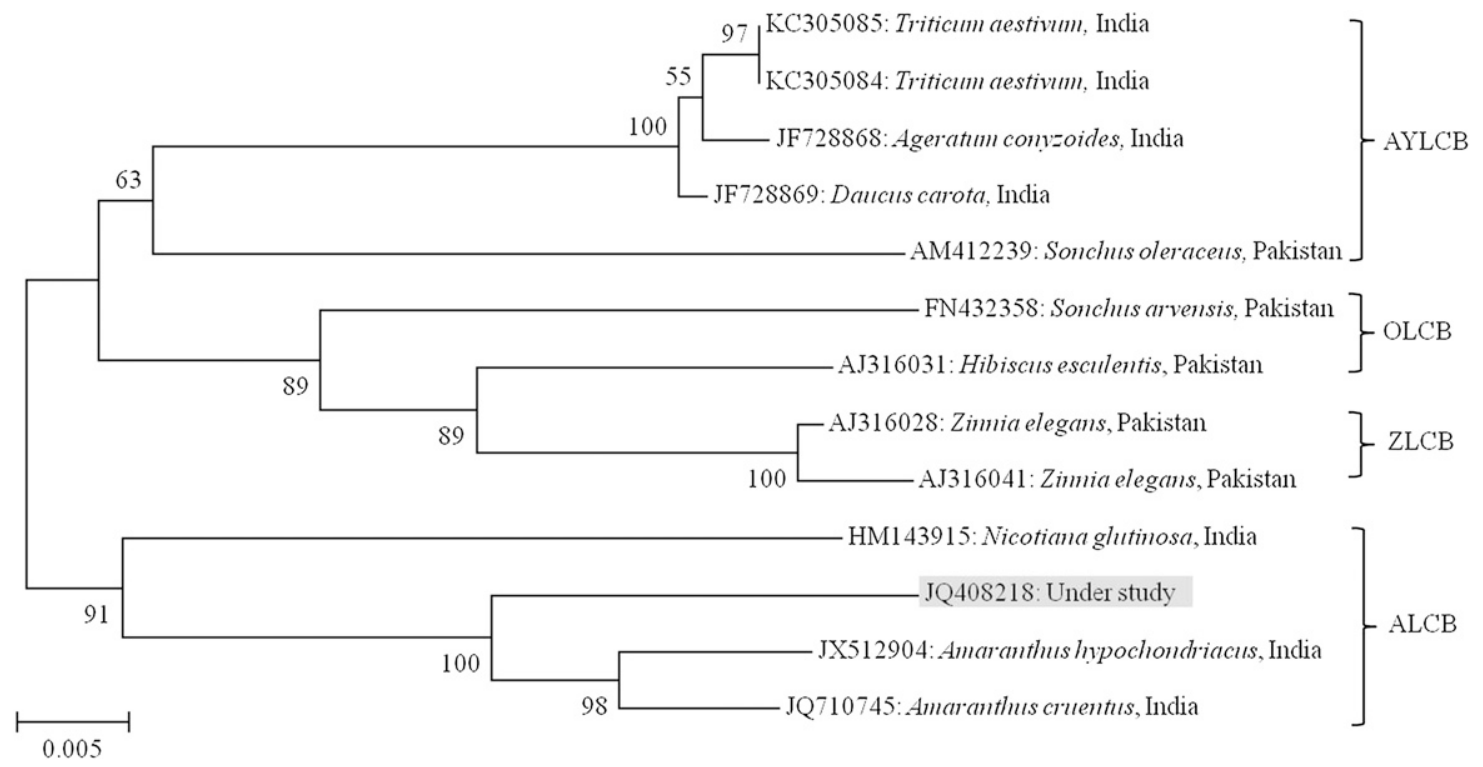

Fig. 3. Phylogenetic relationships of the ALCB under study (JQ408218) of Ageratum houstonianum with some selected betasatellite molecules using MEGA v5.1 with 1,000 replicates bootstrapping and the dendrogram was generated with NJ-method and viewed by NJ plot program. Abbreviations used for this study: AYLCB $=$ Ageratum yellow leaf curl betasatellite, OLCB = Okra leaf curl betasatellite, ZLCB = Zinnia leaf curl betasatellite, and ALCB = Ageratum leaf curl betasatellite. 
alone or in combination can replicate and cause disease while betasatellite is dependent for its replication on helper virus, AEV.

\section{Discussion}

AEV is a whitefly-transmitted monopartite begomovirus containing a single genomic DNA component and was isolated from diseased $A$. conyzoides weed collected from Nepal in 2005 (unpublished data, accession AJ437618). The existence of AEV has also been detected in India on some weeds: Cleome gynandra (18), Crassocephalum crepidioides, and A. conyzoides (12); crop plants: Trichosanthes dioica (19), C. papaya (27), A. cruentus (29), A. hypochondriacus (28), S. lycopersicum (31), and Daucus carota (13); and ornamental plants: Zinnia elegans (14) and T. patula (16). Here, we report characterization and infectivity of AEV and ALCB associated with the yellow vein net disease of $A$. houstonianum.

Literature survey revealed the natural occurrence of Ageratum latent Ilarvirus $(12,25)$ and Ageratum houstonianum potyvirus (unpublished data, GenBank accession AJ867580) on A. houstonianum. AYVV $(33,34)$ from Singapore and AYVCV (35) and ALCV (9) from China have been reported on A. conyzoides. The associations of nanovirus like DNA component (DNA1) (23) and betasatellite ( $\beta$ DNA) (21) with AYVV and with AYVCV (35) have also been reported. Saunders et al. (21) also demonstrated the induction of yellow vein disease of $A$. conyzoides by coinfection of AYVV and $\beta$ DNA, which were similar to yellow vein net disease induced by coinfiltration of AEV genome under study and its associated betasatellite (ALCB) on A. houstonianum.

The occurrence of AEV on A. houstonianum is a new report on a new host that may be considered as a threat to cultivation of commercially important crops in the Asian continent. The spread of AEV in new hosts may be due to the migration/adaptation of whiteflies, a known insect vector for begomovirus transmission (30), from Ageratum sp. to other weeds and commercially important plants in off season when plants of Ageratum sp. are not available for feeding and survival of whiteflies. Tomato severe rugose virus (ToSRV), a begomovirus in Brazil for which successful transfer from naturally infected Crotalaria sp., Euphorbia heterophylla, Nicandra physaloide, and Sida spp. to healthy tomato plants has been demonstrated by biolistic inoculation of RCA amplified DNA, suggesting that the weeds are potential sources of begomoviruses during non-crop season (2).

\section{Acknowledgments}

The authors are thankful to the Director of the CSIR-National Botanical Research Institute, Lucknow for the facilities and Council of Scientific and Industrial Research for the fellowship of Ashish Srivastava.

\section{Literature Cited}

1. Altschul, S. F., Gish, W., Miller, W., Myers, E. W., and Lipman, D. J. 1990. Basic local alignment search tool. J. Mol. Biol. 215:403-410.

2. Barreto, S. S., Hallwass, M., Aquino, O. M., and Inoue-Nagata, A. K. 2013. A study of weeds as potential inoculum sources for a tomato-infecting begomovirus in central Brazil. Phytopathology 103:436-444.

3. Briddon, R. W., Bull, S. E., Amin, I., Idris, A. M., Mansoor, S., Bedford, I. D., Dhawan, P., Rishi, N., Siwatch, S. S., Abdel-Salam, A. M., Brown, J. K., Zafar, Y., and Markham, P. G. 2003. Diversity of DNA beta, a satellite molecule associated with some monopartite begomoviruses. Virology 312: 106-121.

4. Briddon, R. W., Bull, S. E., Amin, I., Mansoor, S., Bedford, I. D., Rishi, N., Siwatch, S. S., Zafar, Y., Abdel-Salam, A. M., and Markham, P. G. 2004. Diversity of DNA 1: a satellite-like molecule associated with monopartite begomovirus-DNA beta complexes. Virology 324:462-474.

5. Brown, J. K. 1994. The status of Bemisia tabaci (Genn.) as a pest and vector in world agroecosystems. FAO Plant Protect. B. 42:3-32.

6. Bull, S. E., Briddon, R. W., and Markham, P. G. 2003. Universal primers for the PCR-mediated amplification of DNA 1: a satellite-like molecule associated with begomovirus-DNA beta complexes. Mol. Biotechnol. 23:83-86.

7. Fauquet, C. M., Briddon, R. W., Brown, J. K., Moriones, E., Stanley, J., Zerbini, M., and Zhou, X. 2008. Geminivirus strain demarcation and nomenclature. Arch. Virol. 153:783-821.

8. Haible, D., Koher, S., and Jeske, H. 2006. Rolling circle amplification revolutionizes diagnosis and genomics of geminiviruses. J. Virol. Methods 135:9-16.

9. Huang, J. F., and Zhou, X. P. 2006. Molecular characterization of two distinct begomoviruses from Ageratum conyzoides and Malvastrum coromandelianum in China. J. Phytopathol. 154, 11-12:648-653.
10. Jia, H. Y., and Fang, R. X. 2003. Rapid communication - agroinoculation as a simple way to deliver a Tobacco mosaic virus based expression vector Acta Bot. Sin. 45:770-773.

11. Johnson, M. F. 1971. A monograph of the genus Ageratum L. (Compositaeeupatorieae). Ann. Mo. Bot. Gard. 58:6-88

12. Klose, M. J., Sdoodee, R., Teakle, D. S., Milne, J. R., Greber, R. S., and Walter, G. H. 1996. Transmission of three strains of tobacco streak ilarvirus by different thrips species using virus-infected pollen. J. Phytopathol. 144 281-284.

13. Kumar, J., Gunapati, S., Singha, S. P., Gadreb, R., Sharma, N. C., and Tuli, R. 2013. Molecular characterization and pathogenicity of a carrot (Daucus carota) infecting begomovirus and associated betasatellite from India. Virus Res. 178:478-485

14. Kumar, Y., Bhardwaj, P., Hallan, V., and Zaidi, A. A. 2010. Detection and characterization of Ageratum enation virus and a nanovirus-like satellite DNA1 from zinnia causing leaf curl symptoms in India. J. Gen. Plant Pathol. 76:395-398.

15. Kumar, Y., Hallan, V., and Zaidi, A. A. 2011. First report of Ageratum enation virus infecting Crassocephalum crepidioides (Benth.) S. Moore and Ageratum conyzoides L. in India. J. Gen. Plant Pathol. 77:214-216.

16. Marwal, A., Sahu, A. K., Choudhary, D. K., and Gaur, R. K. 2013. Complete nucleotide sequence of a begomovirus associated with satellites molecules infecting a new host Tagetes patula in India. Virus Genes 47:194-198.

17. Padidam, M., Beachy, R. N., and Fauquet, C. M. 1995. Classification and identification of geminiviruses using sequence comparisons. J. Gen. Virol. 76:249-263.

18. Raj, S. K., Snehi, S. K., Khan, M. S., Tiwari, A. K., and Rao, G. P. 2010 Detection of Ageratum enation virus from cat's whiskers (Cleome gynandra L.) with leaf curl symptoms in India. J. Gen. Plant Pathol. 76:292-294.

19. Raj, S. K., Snehi, S. K., Tiwari, A. K. and Rao, G. P. 2011. Molecular identification of an Ageratum enation virus isolate associated with mosaic disease of pointed gourd (Trichosanthes dioica) in India. Phytoparasitica 39:497-502.

20. Rojas, M. R., Gilbertson, R. L., Russell, D. R., and Maxwell, D. P. 1993. Use of degenerate primers in the polymerase chain reaction to detect whitefly transmitted geminiviruses. Plant Dis. 77:340-347.

21. Saunders, K., Bedford, I. D., Briddon, R. W., Markham, P. G., Wong, S. M., and Stanley, J. 2000. A unique virus complex causes ageratum yellow vein disease. PNAS 97:6890-6895.

22. Saunders, K., Norman, A., Gucciardo, S., and Stanley, J. 2004. The DNA beta satellite component associated with ageratum yellow vein disease encodes an essential pathogenicity protein (betaC1). Virology 324:37-47.

23. Saunders, K., and Stanley, J. 1999. A nanovirus-like DNA component associated with yellow vein disease of Ageratum conyzoides: evidence for interfamilial recombination between plant DNA viruses. Virology 264:142 152.

24. Shahid, M. S., Ali, L., and Andleeb, S. 2009. The function of the a-rich region of the alphasatellite associated with the cotton leaf curl disease in Pakistan. Eurasian J. BioSci. 3:152-156.

25. Sharman, M., and Thomas, J. E. 2013. Genetic diversity of subgroup 1 ilarviruses from eastern Australia. Arch. Virol. 158:1637-1647.

26. Singh, R., Raj, S. K., and Prasad, V. 2008. Molecular characterization of a strain of Squash leaf curl China virus from North India. J. Phytopathol. 156:222-228.

27. Singh-Pant, P., Pant, P., Mukherjee, S. K., and Mazumdar-Leighton, S. 2012. Spatial and temporal diversity of begomoviral complexes in papayas with leaf curl disease. Arch. Virol. 157:1217-1232.

28. Srivastava, A., Kumar, S., and Raj, S. K. 2014. First report of Ageratum enation virus, betasatellite and alphasatellite causing leaf curl and enation disease of Amaranthus hypochondriacus in India. Plant Dis. 98:1285.

29. Srivastava, A., Raj, S. K., Kumar, S., Snehi, S. K., Kulshreshtha, A., Hallan, V., and Pande, S. S. 2013. Molecular identification of Ageratum enation virus, betasatellite and alphasatellite molecules isolated from yellow vein diseased Amaranthus cruentus in India. Virus Genes 47:584-590.

30. Stanley, J. 2004. Subviral DNAs associated with geminivirus disease complexes. Vet. Microbiol. 98:121-129.

31. Swarnalatha, P., Mamatha, M., Manasa, M., Singh, R. P., and Krishnareddy, M. 2013. Molecular identification of Ageratum enation virus (AEV) associated with leaf curl disease of tomato (Solanum lycopersicum) in India Australas. Plant Dis. Notes 8:67-71.

32. Tamura, K., Peterson, D., Peterson, N., Stecher, G., Nei, M., and Kumar, S 2011. MEGA5: Molecular evolutionary genetics analysis using maximum likelihood, evolutionary distance, and maximum parsimony methods. Mol. Biol. Evol. 28:2731-2739.

33. Tan, H. N. P., and Wong, S. M. 1993. Some properties of Singapore Ageratum Yellow Vein Virus (SAYVV). J. Phytopathol. 139, 2:165-176.

34. Tan, P. H., Wong, S. M., Wu, M., Bedford, I. D., Saunders, K., and Stanley, J. 1995. Genome organization of Ageratum yellow vein virus, a monopartite whitefly-transmitted geminivirus isolated from a common weed. J. Gen. Virol. 76, 12:2915-2922

35. Xiong, Q., Fan, S., Wu, J., and Zhou, X. 2007. Ageratum yellow vein China virus is a distinct begomovirus species associated with a DNA $\beta$ molecule. Phytopathology 97:405-411. 